\section{Relevansi Teori Scarcity Robert Malthus D alam Perspektif Ekonomi Syariah}

\author{
Titin Izzatul M una, M ohammad N urul Qomar* \\ Ekonomi Syariah, Fakultas Ekonomi dan Bisnis Islam, \\ Institut Agama Islam N egeri Kudus
}

\begin{abstract}
A bstract
Purpose- This study is to examine the problem of scarcity related to the theory proposed by Robert $M$ althus and its relevance today. As well as how Islam views the nature of scarcity. M ethods- This research is classified as library research, where the collection of library materials that are relevant to the research topic is the main strength in this research. In addition, this research can be categorized in the study of character studies, namely a systematic and critical study of R obert $M$ althus' $s$ economic thinking related to the theory of scarcity. Findings- In Islamic economics, if we return to the problem of food scarcity that $M$ althus argues is caused by the explosion of population that is not illuminated with the amount of food in the world, then in essence, Allah SWT has bestowed nature and its contents to meet human needs. Every human being already has a part or their respective benefits, so there can be no shortage in terms of food related to the increase in population that occurs. Implications- Ideally $M$ althus's theory reminds us that population growth must still pay attention to environmental sustainability, meaning that it must be adjusted to the carrying capacity and the environmental capacity.
\end{abstract}

\begin{abstract}
A bstrak
Tujuan- Penelitian ini adalah untuk menguji masalah kelangkaan terkait dengan teori yang dikemukakan oleh Robert Malthus dan relevansinya saat ini. Serta bagaimana Islam memandang hakikat kelangkaan. Metode- Penelitian ini diklasifikasikan sebagai penelitian perpustakaan, di mana koleksi bahan pustaka yang relevan dengan topik penelitian adalah kekuatan utama dalam penelitian ini. Selain itu, penelitian ini dapat dikategorikan dalam studi studi karakter, yaitu studi sistematis dan kritis dari pemikiran ekonomi Robert Malthus terkait dengan teori kelangkaan. Temuan- Dalam ekonomi Islam, jika kita kembali ke masalah kelangkaan makanan yang menurut Malthus disebabkan oleh ledakan populasi yang tidak diterangi dengan jumlah makanan di dunia, maka pada intinya, Allah SWT telah menganugerahkan alam dan isinya untuk memenuhi kebutuhan manusia. Setiap manusia sudah memiliki bagian atau manfaatnya masing-masing, sehingga tidak ada kekurangan dalam hal makanan terkait dengan peningkatan populasi yang terjadi. Implikasi- I dealnya, teori Malthus mengingatkan kita bahwa pertumbuhan populasi masih harus memperhatikan kelestarian lingkungan, artinya harus disesuaikan dengan daya dukung dan kapasitas lingkungan.
\end{abstract}

Pedoman Sitasi: Muna, T.I F \& Qomar, M.N (2020). Relevansi Teori Scarcity Robert Malthus Dalam Perspektif Ekonomi Syariah. SERAM BI: Jurnal Ekonomi M anajemen dan Bisnis Islam, 2(1), 1 - 14.

D OI: https:/ / doi.org/ 10.36407/ serambi.v2i1.134

\section{SERAM BI}

Received 7Jan 2020

Revised 15 Feb 2020

Accepted $25 \mathrm{M}$ ar 2020

Online first $30 \mathrm{Apr} 2020$

\section{Paper type}

Literature review

Email :

mnqomar@iainkudus.ac.id

Keywords: Scarcity, Robert $M$ althus, Islamic economics

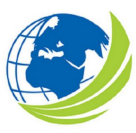

SERAMBI : Jurnal Ekonomi dan Bisnis Islam, Vol 2, No.1, 2020, pp. 1-14

el SSN 2685-9904 


\section{Pendahuluan}

Manusia membutuhkan barang dan jasa dalam memenuhi kebutuhannya. Sementara itu, kebutuhan manusia semakin bertambah dan semakin bervariasi seiring dengan berkembangnya perabadan manusia. Semua permasalahaan manusia dalam memenuhi barang dan jasa, sebenarnya berawal dari adanya gap (kesenjangan) antara ketersediaan sumberdaya (resources) dengan ragam kebutuhan manusia (Rahmawaty, 2011). Mengingat bahwasannya manusia semakin lama bukan semakin sedikit akan tetapi semakin banyak dengan segala kebutuhannya, maka bisa diartikan bahwa kebutuhan akan suatu barang dan jasanya pun semakin meningkat. Berbicara mengenai barang dan jasa, tentunya tidak terlepas dari penyedia/ sumberdaya itu sendiri, baik sumberdaya alam maupun sumberdaya manusia. Sehingga terkait dengan hal ini, dalam ekonomi konvensional muncul yang namanya kelangkaan atau scarcity dimana mereka beranggapan bahwa sumberdaya yang terbatas sementara kebutuhan/ keinginan manusia yang tak terbatas menjadi suatu permasalahan pokok dalam ekonomi.

Salah satu tokoh ekonom kapital is yang memberikan pemikirannya terkait dengan scarcity adalah Thomas Robert Malthus. Menurut Malthus angka peningkatan populasi manusia tidak dibarengi dengan tersedianya jumlah makanan di dunia, sehingga ledakan penduduk baginya adalah ancaman. Malthus menekankan pentingnya untuk melakukan pembatasan laju perkembangan populasi penduduk (Novianto, 2017). Pertumbuhan penduduk mengakibatkan pertambahan kebutuhan manusia akan barang dan jasa. Menurut Thomas Robert Malthus, penduduk bertambah menurut deret ukur $(2,4,8,16,32$, dan seterusnya), sedangkan makanan bertambah menurut deret hitung $(1,2,3,4,5,6$, dan seterusnya). Akibatnya jumlah barang dan jasa, termasuk makanan, tidak seimbang dengan jumlah penduduk (Pieris, 2015). Teori yang dikemukakan oleh Malthus tersebut merupakan sebuah prediksi pesimistik terkait dengan kelangkaan pangan di masa yang akan datang.

Berdasarkan liputan yang dimuat dalam situs berita radio republik Indonesia pada tanggal 20 Juni 2019, dinas tanaman pangan kota Samarinda menyatakan bahwa "akibat cuaca buruk yang terjadi di wilayah Kalimantan Timur termasuk Samarinda berdampak pada kelangkaan bahan pangan" (Khairiyah 2019). Hal ini secara tidak langsung memiliki relevansi dengan teori scarcity yang dikemukakan oleh Malthus, yang mana di daerah tersebut telah terjadi kelangkaan pangan. Akan tetapi yang menjadi penyebab kelangkaan pangan dalam berita di atas bukan karena meledaknya populasi manusia atau penduduk yang ada melainkan disebabkan oleh kondisi cuaca yang buruk sehingga berdampak terhadap produksi pangan di daerah tersebut.

Mengenai kelangkaan, ekonomi kapitalis belum mampu memecahkan persoalan kebutuhan manusia sampai sekarang ini, hal ini diungkap oleh Murasa sebagaimana dikutip oleh Euis Amalia bahwa ada suatu masalah besar dan sangat mendasar dalam ilmu ekonomi konvensional yang mendominasi kajian bidang ilmu ekonomi kontemporer, yaitu ketidakmampuan ilmu tersebut dalam memecahkan persoalan kebutuhan manusia. Teori-teori yang telah ada, terbukti tidak mampu mewujudkan ekonomi global yang berkeadilan. Yang terjadi justru dikotomi antara kepentingan individu, masyarakat dan Negara (Qomar, 2016).

Terkait dangan hal di atas, dalam Alquran sudah dijelaskan bahwa Allah SWT menciptakan manusia di muka bumi dengan sarana yang dapat menunjang kelangsungan kehidupan. Salah satunya dengan menciptakan alat pemuas kebutuhan (barang dan jasa) bagi manusia. Allah SWT menciptakan segala yang ada di langit maupun di bumi untuk manusia, hal ini termaktub pada firman-Nya dalam QS. al-Baqarah/ 2: 29 yaitu: 
Artinya: Dia-lah Allah, yang menjadikan segala yang ada di bumi untuk kamu dan Dia berkehendak (menciptakan) langit, lalu dijadikan-Nya tujuh langit. dan Dia Maha mengetahui segala sesuatu.

Sayyid Quthb menafsirkan bahwa perkataan "untuk kamu" dalam ayat ini memiliki makna yang dalam dan memiliki kesan yang dalam pula. Ini merupakan kata pasti yang menetapkan bahwa Allah menciptakan manusia ini untuk urusan yang besar. Diciptakan-Nya manusia untuk menjadi khalifah di muka bumi, menguasai dan mengelolahnya. Mereka adalah makhluk tertinggi di dalam kerajaan yang terhampar luas ini, dan merekalah majikan pertama dalam warisan yang banyak ini (Qutb, 2008).

Begitulah Allah SWT telah mencipatakan bumi beserta manusia sebagai khalifah nya. Maka setelah adanya penciptaan tersebut, apakah masih ada yang kurang dengan semua itu? A pakah kelangkaan itu benar-benar ada? Dan sebagainya. Hal ini lah yang mendorong penulis untuk mengkaji masalah kelangkaan atau scarcity terkait dengan teori yang diajukan ol eh Robert Malthus tersebut dan relevansinya di zaman sekarang. Serta bagaimana pandangan Islam tentang hakikat kelangkaan itu sendiri.

\section{Kajian Pustaka \\ Biografi R obert Malthus}

Thomas Robert Malthus, FRS (lahir di Surrey, Inggris, 13 Februari 1766-meninggal di Haileybury, Hertford, Inggris, 29 Desember 1834 pada umur 68 tahun), yang biasanya dikenal sebagai Thomas Malthus, meskipun ia lebih suka dipanggil "Robert Malthus", adalah seorang pakar demografi Inggris dan ekonom politk yang paling terkenal karena pandangannya yang pesimistik namun sangat berpengaruh tentang pertambahan penduduk.

Malthus dilahirkan dalam sebuah keluarga yang kaya. Ayahnya, Daniel, adalah sahabat pribadi filsuf dan skeptik David Hume dan kenalan dari Jean-Jacques Rousseau. Malthus muda dididik di rumah hingga ia diterima di Jesus College, Cambridge pada 1784. Di sana ia belajar banyak pokok pelajaran dan memperoleh penghargaan dalam deklamasi Inggris, bahasa Latin dan Yunani. Mata pelajaran utamanya adalah matematika. Ia memperoleh gelar magister pada 1791 dan terpilih menjadi fellow dari Jesus College dua tahun kemudian. Pada 1797, ia ditahbiskan dan menjadi pendeta Anglikan di desa.

Malthus menikah pada 1804; ia dan istrinya mempunyai tiga orang anak. Pada 1805 ia menjadi profesor Britania pertama dalam bidang ekonomi politik di East India Company College di Haileybury di Hertfordshire. Siswa-siswanya menyapanya dengan sebutan kesayangan "Pop" (yang dapat berarti "papa") "Populasi" Malthus. Pada 1818, ia terpilih menjadi Fellow dari Perhimpunan Kerajaan (Wikipedia, 2019).

\section{Teori Scarcity Perspektif Robert Malthus}

Istilah krisis selalu dikaitkan dengan tidak seimbangnya antara supply (ketersediaan) dengan demand (kebutuhan), yaitu ketika angka kebutuhan lebih tinggi dari ketersediaan, maka terjadilah krisis. Kekhawatiran terhadap krisis pangan pertama dinyatakan oleh Thomas Robert Malthus (1766-1834), bahwa laju pertambahan penduduk meningkat berdasarkan deret ukur, sedangkan produksi pangan berdasar deret hitung. Deret ukur dalam pemahaman Malthus diartikan sebagai terjadinya peningkatan berdasar kelipatan yakni: 1, 2, 4, 8, dan seterusnya. Sedangkan deret hitung menjelaskan bahwa peningkatan terjadi berdasar penambahan tetap dengan angka variabel penambah 1, yakni 1, 2, 3, 4 dan seterusnya. Dapat dikatakan bahwa teori Malthus 
mengingatkan bahwa secara alamiah generasi yang akan datang akan memiliki permasalahan yang lebih kompleks berkaitan dengan ketersediaan pangan, dibanding dengan generasi sebelumnya (Pieris, 2015).

Malthus ini bisa dibilang ahli ekonomi yang paling disalahpahami sepanjang masa. Kata sifat "Malthus" yang digunakan saat ini untuk menggambarkan prediksi pesimis kund-langkah kematian dari manusia ditakdirkan untuk kelaparan melalui kelebihan populasi. Menulis sebelum revolusi industri, Malthus tidak bisa sepenuhnya menghargai dampak dari teknologi (yaitu, pestisida, pendingin, mekanik peralatan pertanian, dan peningkatan hasil panen) pada produksi pangan. Meskipun ia dikenal karena peringatan mengerikan melawan kelebihan penduduk, Malthus tidak menentang pertumbuhan penduduk per se. Sebaliknya, ia menentang pertumbuhan yang akan melampaui suplai makanan. Dia memperkirakan bahwa populasi akan tumbuh secara geometris, sementara pasokan makanan akan meningkat hanya deret hitung, sehingga kelaparan massal. Meskipun Malthus meramalkan undersupply bencana komoditas dalam jangka panjang, ia percaya mungkin ada kelebihan pasokan umum dalam jangka pendek. oversupplies ini, yang ia sebut "gluts," menurut pendapatnya, faktor pencegah dari ketidakseimbangan penduduk dan manusia antara lain Preventive checks (penundaan perkawinan, mengendalikan hawa nafsu dan pantangan kawin), Possitive checks (bencana alam, wabah penyakit, kejahatan dan peperangan). Robert Malthus ini mengemukakan beberapa pendapat tentang kependudukan, yaitu :

1. Penduduk (seperti juga tumbuhan dan binatang) apabila tidak ada pembatasan akan berkembang biak dengan sangat cepat dan memenuhi dengan cepat beberapa bagian dari permukaan bumi.

2. Manusia untuk hidup memerlukan bahan makanan, sedangkan laju pertumbuhan makanan jauh lebih lambat (deret hitung) dibandingkan dengan laju pertumbuhan penduduk (deret ukur) (Conway, 2015).

\section{Kebangkitan Kembali Teori Malthus: Neo-Malthusian}

Salah satu ide Malthus yang kontroversial adalah ia menawarkan solusi preventif agar masyarakat menahan laju pertumbuhan penduduk dengan pembatasan dan penangguhan. Solusi ini tentu benar dan tepat, tapi tidak sertamerta dipraktikkan masyarakat. Berbagai catatan survei yang ditulis Huxley menunjukkan, masyarakat cenderung mengabaikan soal pembatasan, sekalipun mereka dalam kondisi penderitaan dan kemiskinan. Di beberapa daerah di negara miskin misalnya, derita kehidupan mereka tidak menyurutkan hasrat reproduksi massal. Soal kemauan masyarakat menerima pembatasan anak sangat terkait dengan tingkat kualitas sumber daya manusia (SDM). Masyarakat yang sadar akan pentingnya kehidupan yang berkualitas, akan dengan sendirinya memahami pembatasan anak sebagai hal yang penting.

Kendati Malthus tak pernah menganjurkan adanya pengendalian penduduk lewat alat kontrasepsi, usul macam itu merupakan konsekuensi yang lumrah dari ide pokoknya. Orang pertama yang secara terbuka menganjurkan penggunaan alat kontrasepsi secara luas untuk mencegah kebanyakan penduduk adalah seorang pembaharu Inggris yang berpengaruh, Francis Place (1771-1854). Place yang membaca esai Malthus dan amat terpengaruh olehnya, menulis buku tahun 1822, yang isinya menganjurkan kontrasepsi. Dia juga membagi-bagi penjelasan tentang pembatasan kelahiran diantara para kelas pekerja.

Di Amerika Serikat, Dr. Charles Knowlton menerbitkan buku tentang kontrasepsi tahun 1832. "Lembaga Malthus" pertama dibentuk tahun 1860 dan anjuran keluarga berencana dengan demikian semakin bertambah penganutnya. Karena Malthus sendiri tidak menyetujui --atas 
dasar alasan moral-- penggunaan alat kontrasepsi, anjuran pembatasan kenaikan jumlah penduduk dengan menggunakan alat-alat kontrasepsi biasanya disebut "neo-Malthusian."

Beberapa tokoh neo- Malthusian yang cukup menonjol ialah Paul Ehrlich (ahli biologi di Universitas Stanford) dan Garret Hardin (ahli biologi di Universitas California). Tahun 1871 Ehrlich menulis buku "The Population Bomb" dan kemudian direvisi menjadi "The Population Explotion" yang berisi; pertama, Sudah terlalu banyak manusia di bumi ini; kedua, Keadaan bahan-bahan makanan sangat terbatas; dan ketiga, Lingkungan rusak sebab populasi manusia meningkat (Subair, 2015).

Teori Scarcity Perspektif Baqir As Shadr

Muhammad Baqir al-Sadr lahir di kota Khadhimiyah Baghdad Irak pada tanggal 1 Maret 1935 M / 25 Dzul Qa'dah 1353 H.8 Beliau belajar ilmu mantiq, ushul figh di bawah asuhan saudara tertuanya, Ismail al-Sadr. Kemudian melanjutkan pendidikannya di kota Najaf, berguru kepada Ayatullah 'Udhma Syeikh Ridho al Yasin dan Ayatullah 'Udhma Abul Qosim. Dua karya Baqir al-Sadr yang sangat terkenal, yaitu Falsafatuna dan Iqtidhaduna. Falsafatuna di terbitkan tahun 1959 yang meliputi antara lain; 13 kritik komunisme, pemikiran materialis. Iqtishaduna diterbitkan tahun 1961 mengkritisi teori ekonomi kapitasime dan sosialisme (Qomar, 2016).

Menurut Islam masalah-masalah ekonomi bukan disebabkan oleh kelangkaan sumbersumber material atau alat pemuas kebutuhan maupun terbatasnya kekayaan alam. Memang benar bahwa sumber-sumber produksi terbatas, sementara kebutuhan manusia banyak dan beragam. Namun, bukan berarti bahwa masalah ekonomi yang dihadapi oleh manusia muncul dari akibat kebutuhan manusia yang tidak terbatas. Pendapat yang menyatakan bahwa masalah ekonomi muncul karena adanya kelangkaan, ini dapat dibantahkan karena hal tersebut merupakan semacam pengindraan terhadap penyebab yang sebenarnya ada sol usinya (as-Shadr, 2008).

Baqir al-Sadr menyebut masalah ekonomi terkait dengan kelangkan bersifat imajiner. Beliau mempunyai pendapat bahwa Allah SWT sebagai pencipta manusia mengetahui kebutuhan manusia sehingga Allah SWT telah menyediakan ketersediaan kebutuhan manusia, sehingga bukan ketersediaan sumber daya alam yang menjadi masalah utama ekonomi, tetapi manusia yang menyebabkan masalah ekonomi. Pendapat beliau ini didasarkan pada surat Ibrahim ayat 32-34:

"Allah SWT yang telah menciptakan langit dan bumi dan menurunkan air hujan dari langit, kemudian mengeluarkan dengan air hujan itu berbagai buah-buahan sebagai rejeki untukmu. Menundukkan lautan bagimu untuk berlayar dengan kehendakNya, menundukkan matahari dan bulan untukmu yang terus menerus beredar (dalam orbitnya), menundukkan malam dan siang untukmu dan Dia telah memberikan segala sesuatu yang kamu mohonkan kepadaNya. Dan jika kamu menghitung nikmat dari Allah SWT, tidaklah kamu mampu menghitungnya. Sesungguhnya manusia sangat dhalim dan sangat mengingkari nikmat."

Pendapat Baqir al-Sadr ini berimplikasi pada nilai tauhid, di mana Allah SWT menyediakan sumber daya alam sangat banyak untuk memenuhi kebutuhan manusia. Manusia yang berperan sebagai khalifah, dapat memanfaatkan sumber daya yang banyak itu untuk kebutuhan hidupnya. Selanjutnya melalui ayat tersebut, Baqir al-Sadr ingin menunjukkan bahwa masalah utama ekonomi adalah kedhaliman dan kekufuran manusia (Qomar, 2016).

Teori Scarcity Perspektif M adzhab M ainstream

Tokoh mazhab ini antara lain Umar Chapra, Metwally, M. A. Mannan, M. N. Siddiqi, dan Iain- 
Iain. Mayoritas mereka adalah para pakar ekonomi yang belajar serta mengajar di universitas Barat dan sebagian besar diantara mereka seorang ekonom Islamic Development Bank (IDB)(AIArif, 2017). Tokoh-tokoh mazhab mainstream juga memberikan sumbangan terkait dengan masalah kelangkaan. Berbeda dengan madzhab Baqir, mazhab kedua ini justru setuju bahwa masalah ekonomi muncul karena sumber daya yang terbatas yang dihadapkan pada keinginan manusia yang tidak terbatas. Memang benar misalnya, bahwa total permintaan dan penawaran beras di seluruh dunia berada pada titik equilibrium. Namun pada waktu dan tempat tertentu sangat mungkin terjadi kelangkaan sumber daya pada satu tempat dan kel impahan sumber daya pada tempat yang lain (Karim, 2001).

Dalil yang digunakan oleh mereka adalah AI Quran surat AI Baqarah ayat 155 (AI-Arif, 2017): "dan sungguh akan Kami berikan cobaan kepadamu, dengan sedikit ketakutan, kelaparan, kekurangan harta, jiwa dan buah-buahan. dan berikanlah berita gembira kepada orang-orang yang sabar." Jadi, keterbatasan sumber daya memang ada paling tidak hal ini bisa terjadi di suatu tempat dan waktu tertentu.

Mazhab mainstream adalah suatu mazhab yang memiliki pandangan bahwa perbedaan utama antara ilmu ekonomi konvensional dengan ilmu ekonomi islam terletak pada cara untuk mencapai tujuan ilmu ekonomi tersebut, dimana mazhab mainstream menyetujui pandangan ilmu ekonomi konvensional yang menyatakan bahwa ekonomi muncul karena adanya keterbatasan sumber daya ekonomi untuk memenuhi kebutuhan manusia yang tidak terbatas.

Pandangan madzhab mainstream tidak ada bedanya dengan pandangan ekonomi konvensional. Titik pangkal persoalan ekonomi menurut mereka adalah kelangkaan sumberdaya. Namun meskipun sama-sama memandang kelangkaan sebagai titik masalah, tentu saja madzhab mainstream tetap berbeda dengan ekonomi konvensional. Letak perbedaannya adalah madzhab mainstream menegaskan pilihan dalam menata prioritas ekonomi itu tidak bisa diatur semaunya saja. Sebab, prilaku manusia dalam segala aspeknya tak terkecuali masalah ekonomi, diatur dan dipandu oleh AI-Qur'an. Pandangan inilah yang dipopulerkan oleh antara Iain M. Umer Capra, MA Mannan, dan Monzer Khaf (Setiawan, 2019).

\section{M etode Penelitian}

Penulis menggunakan jenis penelitian kepustakaan (library research) yaitu suatu upaya mendapatan bahan-bahan yang diperlukan dengan membaca buku-buku dan karya-karya ilmiah yang relevan, termasuk tulisan yang dipublikasikan di berbagai media cetak maupun elektronik. Selain itu penelitian ini dapat dikategorikan dalam penelitian life history (studi tokoh), yaitu pengkajian secara sistematis dan kritis terhadap pemikiran ekonomi Robert Malthus terkait dengan konsep scarcity. Pendekatan penelitian yang dilakukan oleh penulis adalah pendekatan metodologi secara normatif dan sosiologis, yaitu riset yang berdasarkan pada al-Quran dan menggunakan analisis terhadap suatu objek permasalahan, serta bersifat understanding (memahami) terhadap fenomena atau gejala sosial. Penelitian ini yang bertolak dari data, memanfaatkan teori yang ada sebagai bahan penjelas dan berakhir pada suatu kesimpulan dari hasil penelitian.

Pengelolahan data menggunakan teknik-teknik pengutipan langsung dan tidak langsung. Kutipan langsung, yaitu penulis mengutip pendapat atau tulisan orang secara lansung sesuai dengan aslinya, tanpa sedikitpun mengubah susunan redaksinya. Sedangkan kutipan tidak langsung, yaitu mengutip pendapat orang lain dengan cara menambah atau mengurangi susunan redaksinya dengan mengganti susunan redaksi yang baru tanpa mengubah makna atau isi redaksinya sebelumnya. Setelah penulis mengumpulkan data dari berbagai literatur yang ada 
maka data tersebut siap untuk diolah.

\section{Hasil dan Diskusi}

Dalam perspektif ekonomi syariah, terkait dengan teori scarcity (kelangkaan) para pemikir ekonom muslim terbagi menjadi beberapa madzhab yang memiliki pendapat masing-masing sebagaimana telah dijelaskan sebelumnya. Kedua madzhad tersebut memang memiliki tanggapan yang berbeda terkait dengan kelangkaan. Namun, pada prinsipnya keduanya samasama mengakui akan adanya kelangkaan. Dari sisi madzhab Baqir, kelangkaan terjadi dikarenakan adanya ketidakmerataan distribusi sedangkan dari sisi madzhab mainstream kelangkaan bisa saja terjadi dan dipengaruhi oleh faktor permintaan dan juga penawaran yang terjadi di suatu daerah tertentu.

Pandangan mazhab mainstream ini tentang masalah ekonomi hampir tidak ada bedanya dengan pandangan ekonomi konvensional. Kelangkaan sumber dayalah yang menjadi penyebab munculnya masalah ekonomi. Perbedaannya terletak dalam cara menyelesaikan masalah tersebut. Dengan adanya kenyataan bahwa sumber daya yang terbatas versus keinginan yang tak terbatas memaksa manusia untuk melakukan pilihan-pilihan atas keinginannya. Oleh karena itu manusia membuat skala prioritas pemenuhan keinginan, dari yang paling penting sampai yang paling tidak penting. Dalam ekonomi konvensional, pilihan dan penentuan skala prioritas dilakukan berdasarkan selera pribadi masing-masing. Manusia boleh mempertimbangkan tuntutan agama, boleh juga mengabaikannya. Tetapi dalam ekonomi Islam, keputusan pilihan ini tidak dapat dilakukan semaunya saja. Perilaku manusia dalam setiap aspek kehidupannya, termasuk ekonomi, selalu dipandu oleh Allah melalui Alquran dan Sunnah.

Pandangan sistem kapital is yang menyamakan antara pengertian kebutuhan (need) dengan keinginan (want) adalah tidak tepat dan tidak sesuai dengan fakta. Keinginan (want) manusia memang tidak terbatas dan cenderung untuk terus bertambah dari waktu ke waktu. Sementara kebutuhan manusia tidaklah demikian. Bila dikaji secara mendalam, kebutuhan manusia ada yang merupakan merupakan kebutuhan pokok (al hajat al asasiyah) dan ada kebutuhan yang sifatnya pelengkap (al hajat al kamaliyat), yakni berupa kebutuhan sekunder dan tersier.

Kebutuhan pokok manusia berupa pangan, sandang dan papan dalam kenyataannya adalah terbatas. Setiap orang yang kenyang setelah memakan makanan tertentu, maka pada saat itu sebenarnya kebutuhannya telah terpenuhi dan dia tidak memerlukan makanan yang lain. Juga, orang yang sudah memiliki pakaian tertentu meskipun hanya beberapa potong saja, maka sebenarnya kebutuhan dia akan pakaian sudah terpenuhi. Demikian juga jika orang telah menempati suatu rumah tertentu sebagai tempat tinggalnya meskipun sekadar menyewa, sebenarnya kebutuhannya akan rumah tinggal juga sudah terpenuhi. Dan jika manusia sudah mampu memenuhi kebutuhan-kebutuhan pokoknya itu, sebenarnya dia sudah dapat menjalani kehidupan ini tanpa mengalami kesulitan yang berarti (Ulum, 2017).

Adapun pemikiran Thomas Robert Malthus tersebut memicu pemerintahan untuk menggalakkan dua hal, yaitu program Keluarga Berencana (KB) dan atau meningkatkan produksi nasional (PDB). Demikian pula pemikiran ekonomi dari JB. Say yang mendukung pemikiran Malthus untuk meningkatkan produksi nasional, sebab penawaran itu akan menghasilkan permintaannya sendiri, artinya setiap produksi yang dihasilkan akan mampu dibeli/ diserap oleh konsumen/ masyarakat. Dengan begitu, produksi harus terus ditingkatkan demi mengatasi problem ekonomi dalam pandangan mereka, yaitu Scarcity (kelangkaan) (Dwijaya, 2013).

Teori Malthus mengenai kelangkaan pangan yang disebabkan oleh adanya ledakan 
penduduk merupakan suatu pemikiran yang pesimistik. Dimana Malthus tidak mempertimbangkan akan adanya perubahan-perubahan di masa depan. Perubahan-perubahan yang dimaksud di sini adalah seperti halnya dengan kemajuan ilmu pengetahuan serta teknologi dimana hal ini akan memunculkan alternatif-alternatif untuk menangani kebutuhan pangan masyarakat.

Pada kenyataannya sampai saat ini, teori scarcity yang dikemukakan oleh Malthus masih menjadi bahan perbincangan oleh beberapa ahli ekonomi dan juga di beberapa perguruan tinggi. Dalam beberapa situs blog yang penulis baca, teori Malthus tersebut ternyata masih santer dibicarakan, baik itu mengkritisi, merelevansikannya dengan fenomena saat ini dan juga terkait dengan pembuktian teori. Hal ini sesuai dengan pernyataan Subair dalam jurnalnya bahwa sampai hari ini meskipun dikritik dengan berbagai argumen dan dianggap terlalu pesimistik melihat masa depan manusia, teori Malthus itu masih relevan untuk dibicarakan, bahkan dianut. Tentu saja tidak lagi secara utuh dalam versinya yang lama melainkan transformasinya dalam bentuk teori-teori neo-Malthusian(Subair, 2015).

Relevansi teori Malthus dengan fenomena saat ini sebagaimana dalam sebuah artikel yang dimuat oleh Kompasiana, bahwa jika dilihat dari kenyataan saat ini, manusia memang telah memperebutkan pangan melalui persaingan kerja, yang mana kita saling berlomba untuk memperoleh pekerjaan, dan berharap untuk bertahan hidup darinya, hal itu direfleksikan sebagai perebutan pangan dalam teori Malthus. Lalu terkait dengan ketahanan pangan di Indonesia saat ini, lahan di Indonesia terutama di desa semakin terkikis habis karena pembangunan gedung atau rumah baru. Akibatnya kini produksi agraris di Indonesia kurang maksimal (Putri, 2015). Terkait dengan artikel tersebut, penulis menemukan adanya kelemahan dalam teori Robert Malthus, yaitu bahwa dalam teori Malthus komoditi tidak dipertukarkan dengan komi diti, tetapi dengan tenaga kerja.

Solusi yang ditawarkan dari para pakar ilmu ekonomi konvensional dalam mengatasi yang namanya kelangkaan yaitu dengan meningkatkan kualitas dan jumlah produksi. Namun, jika kita cermati tentang ayat-ayat yang menyangkut produksi dalam al-Qur'an semua hanya berujuk pada perintah yang bersifat umum. Misalnya saja dalam QS al-Hadid/57: 25 Allah SWT berfirman yaitu:

“...Dan Kami Menciptakan besi yang mempunyai kekuatan hebat dan banyak manfaat bagi manusia..."

Jika dalil tersebut bersifat umum dan tidak ada dalil yang mengkhususkannya maka akan tetap pada keumumannya. Dan dalil yang bersifat umum bersifat mubah bagi manusia yaitu diserahkan kepada akal manusia karena akal manusia mampu melakukannya. Dalam ayat tersebut Allah SWT tidak menyebutkan secara spesifik tentang pemberian besi untuk dimanfaatkan oleh manusia. Allah SWT juga memberikan penjelasan bahwa, besi tersebut memiliki kekuatan yang bersifat dahsyat jika manusia mau memanfaatkannya. Namun, Allah SWT tidak memberikan rincian khusus cara memproduksinya atau memanfaatkannya, semuanya dikembalikan pada akal manusia (Triono, 2011).

Berbeda ketika Allah SWT menyebutkan tentang distribusi (perpindahan harta) misalnya ayat tentang warisan. Allah SWT berfirman dalam QS. an-Nisa/ 4: 11 yaitu:

"Allah mensyari'atkan bagimu tentang (pembagian pusaka untuk) anak-anakmu. Yaitu : bahagian seorang anak lelaki sama dengan bagahian dua orang anak perempuan; dan jika anak itu semuanya perempuan lebih dari dua, Maka bagi mereka dua pertiga dari harta yang ditinggal kan; jika anak perempuan itu seorang 
saja, Maka ia memperoleh separo harta. dan untuk dua orang ibu-bapa, bagi masingmasingnya seperenam dari harta yang ditinggalkan, jika yang meninggal itu mempunyai anak; jika orang yang meninggal tidak mempunyai anak dan ia diwarisi oleh ibu-bapanya (saja), Maka ibunya mendapat sepertiga; jika yang meninggal itu mempunyai beberapa saudara, Maka ibunya mendapat seperenam. (Pembagianpembagian tersebut di atas) sesudah dipenuhi wasiat yang ia buat atau (dan) sesudah dibayar hutangnya. (Tentang) orang tuamu dan anak-anakmu, kamu tidak mengetahui siapa di antara mereka yang lebih dekat (banyak) manfaatnya bagimu. ini adalah ketetapan dari Allah. Sesungguhnya Allah Maha mengetahui lagi Maha Bijaksana."

Berdasarkan ayat tersebut maka dapat disimpulakan bahawa otak manusia tidak mampu menyelesaikan perkara distribusi, sebab Allah menjelaskan secara rinci mengenai pembagian harta warisan terhadap ahli waris dimana hal ini merupakan salah satu bentuk pendistribusian harta. Karena otak manusia tidak mampu mnyelesaikan perkara distribusi maka inilah yang menjadi pokok permasalahan dalam ekonomi. Sementara dalam segala proses penyelesaiannya harus berdasarkan pada bimbingan wahyu baik itu bersumber dari Alquran maupun Sunnah.

jika semua pakar ekonomi beranggapan bahwa kelangkaan adalah masalah utama yang dihadapi oleh manusia di muka bumi ini, maka solusi yang mereka berikan adalah dengan cara peningkatan kualitas dan jumlah produksi. Hal ini lah yang akan mendorong peningkatan produksi besar-besaran oleh suatu negara dalam ekonomi makro dan kurangnya konsentrasi pada distribusi dari hasil produksi tersebut.

Kurangnya konsentrasi pada distribusi kekayaan akan menyebabkan monopoli kepemilikan. Orang yang mempunyai modal besar akan mendapatkan harta atau kekayaan yang banyak pula, sebaliknya orang yang memiliki modal yang kurang (sedikit) akan mendapatkan harta atau kekayaan yang sedikit pula. Dengan demikian akan menciptakan masyarakat kaya akan semakin kaya dan masyarakat miskin akan semakin miskin. Kesenjangan sosial dalam masyarakan pun terjadi dan akan memicu terjadinya penindasan atau kesewenangan kepada si miskin dan iri hati kepada kaum kaya. Dari kesenjangan menjadi faktor domino kepada yang lain yaitu akan menyebabkan penyimpangan-penyimpangan sosial, misalnya pencuriaan, perampokan, penipuan dan penculikan. Dari semua itu, maka peningkatan jumlah produksi dalam mengatasi permaslahan ekonomi tidak dapat diwujudkan. Kerena pokok permasalahan ekonomi tidak terletak pada kelangkaan al at pemuas kebutuhan yang harus disel esaikan dengan proses produksi besar-besaran.

Sebagai ummat Muslim dalam menajalani kehidupannya di dunia ini sudah sepatutnya sadar akan hubungannya dengan Allah SWT. Artinya, di dalam menjalani kehidupan ini maka segala persoalan hidup manusia hendaknya diserahkan kepada Allah SWT selaku pencipta manusia Yang Maha Mengetahui segala ciptaan-N ya termasuk kebutuhan manusia. Berdasarkan hal tersebut maka seluruh amal perbuatan manusia harus diatur berdasarkan perintah dan larangan Allah SWT, yang dilandasi oleh kesadaran manusia akan hubungannya dengan Allah SWT sehingga akan terwujudlah yang namanya ruh dalam amal-amal perbuatannya. Dengan demikian, manusia akan menyesuaikan setiap amal perbuatannya dengan perintah Allah SWT dan larangan- Nya berdasarkan kesadaran akan hubungannya dengan Allah SWT (an-Nabhani, 2011).

Sebagaimana ayat yang terkandung dalam Q.S. I brahim ayat 32-34 dan juga dalam Q.S. AIBaqarah ayat 155, jika kita mengkombinasikan makna dari keduanya maka kita dapat menarik kesimpulan bahwa setiap manusia yang hidup di dunia sudah diberikan rizkinya masing-masing 
termasuk akan kebutuhan pangannya. Hal ini sesuai dengan pendapat Baqir al-Sadr yang berimplikasi pada nilai tauhid, di mana Allah SWT menyediakan sumber daya alam sangat banyak untuk memenuhi kebutuhan manusia. Manusia yang berperan sebagai khalifah, dapat memanfaatkan sumber daya yang banyak itu untuk kebutuhan hidupnya. Selanjutnya melalui ayat tersebut, Baqir al-Sadr ingin menunjukkan bahwa masalah utama ekonomi adalah kedzaliman dan kekufuran manusia (Qomar, 2016). Jadi setiap pertambahan populasi manusia di dunia pada hakikatnya Allah SWT pun telah menyiapkan kebutuhan hidupnya. Manusia dengan segala anugerah dari Allah SWT di dunia, memiliki kewajiban untuk mengelola dan juga mengolah sumber daya yang ada dengan baik dan benar demi kelangsungan hidup masa sekarang maupun masa mendatang. Namun, sebagaimana disebutkan dalam Q.S. AI-Baqarah ayat 155, bahwasannya sebagai bentuk rasa kasih Allah SWT kepada manusia maka sesekali Allah SWT memberikan cobaan, salah satunya yaitu berupa kelaparan yang direfleksikan sebagai kelangkaan pangan seperti halnya yang dimuat dalam berita di atas bahwasannya terjadi kelangkaan pangan di Samarinda karena faktor cuaca.

Kedzaliman manusia dalam hal distribusi kekayaan dan keingkaran mereka terhadap nikmat Allah SWT (dengan semena-mena mengeksploitasi sumber-sumber yang Allah anugerahkan kepada mereka) adalah dua faktor yang menciptakan kesesengsaraan hidup manusia sejak awal sejarah. Masalah ini dapat diatasi dengan mengakhiri kedzaliman dan keingkaran manusia, yakni dengan menciptakan hubungan ynag baik antara distribusi dan mobilisasi segenap sumber daya material untuk memakmurkan alam dan kehidupan manusia itu sendiri (As Shadr, 2008).

Pelarangan eksploitasi dan pemusatan kekayaan hanya pada satu pihak pada dasarnya dikarenakan hal tersebut merupakan suatu tindakan yang dilarang dalam Islam, dan termasuk suatu kedzaliman. Tindakan eksploitasi tentunya memiliki dampak yang sangat buruk bagi masa depan umat manusia. Yang mana tindakan ini bisa menimbulkan kerusakan-kerusakan sumber daya yang ada sehingga di masa mendatang hal tersebut akan berakibat buruk bagi kelangsungan hidup manusia.

Kebijakan distribusi dalam pandangan Islam merupakan kebijakan yang membatasi peredaran harta dan sumber daya di kalangan orang-orang kaya saja. Untuk itulah kebijakan distribusi yang ditawarkan dalam ekonomi Islam sangat bertolak belakang dengan kebijakan ekonomi kapitalis yang berpijak pada metode pertumbuhan ekonomi. Prinsip utama distribusi dalam Islam adalah peningkatan dan pembagian bagi hasil kekayaan agar sirkulasi kekayaan dapat ditingkatkan sehingga kekayaan yang ada dapat meilmpah dengan merata dan tidak hanya beredar di antara golongan tertentu saja (Aprianto, 2016).

Sesungguhnya masalah kependudukan sudah menjadi masalah yang sudah lama diperdebatkan oleh para ahli. Arus utama dalam perdebatan itu adalah suatu optimisme yang kuat akan kemampuan manusia memenuhi kebutuhannya meskipun dalam jumlah yang banyak dan terus bertambah melalui berbagai cara seperti peningkatan produksi melalui industrialisasi, pembukaan koloni atau lahan baru, peningkatan produksi pertanian dan yang terutama melalui kemajuan ilmu pengetahuan(Subair, 2015).

Jika dilihat dalam perspekif ekonomi syariah, keterbatasan pangan yang terjadi pada zaman sekarang bukan dikarenakan ketidakmampuan alam dalam menyediakan sumber daya pangan, akan tetapi merupakan suatu akibat dari tindakan manusia itu sendiri dimana proses produksi yang secara berlebih-lebihan sehingga dilakukannya eksploitasi sumber daya yang ada menimbulkan kerusakan dan berdampak pada kelangsungan hidup manusia. Hal inilah yang sebenarnya menjadi penyebab kelangkaan pangan bukan pesatnya pertumbuhan penduduk 
sebagaimana teori yang dikemukakan oleh Malthus.

Berdasarkan berita yang dimuat dalam Liputan6.com menyatakan bahwa "terdapat keterpurukan yang siap melanda tanah air, hal ini dimulai dari kurangnya minat kaum muda untuk bekerja di sektor pertanian, keterbatasan lahan, keterbatasan sumber pangan, hingga keamanan pangan agar layak dikonsumsi masyarakat" (Maris, 2019). Terkait dengan keterbatasan lahan pangan dan sumber pangan, dengan kemajuan teknologi di era saat ini, maka sangat memungkinkan adanya perubahan pola produksi pangan untuk pemenuhan kebutuhan manusia dimana banyak bermunculan teknologi serta media yang dan dapat digunakan untuk menghasilkan produk pangan dan juga sumber pangan baru. Yang menjadi masalah utama di sini bukanlah keterbatasan lahan ataupun sumber pangan akan tetapi minimnya minat masyarakat terlebih kaum muda terhadap sektor pertanian menjadi suatu masalah tersendiri dimana ketika hal ini berlangsung secara berkepanjangan maka akan menimbulkan dampak yang buruk bagi kelangsungan pangan di masa yang akan datang.

\section{Kesimpulan}

\section{Kesimpulan}

Dalam ekonomi syariah, adanya kesadaran manusia sebagai seorang muslim bahwa segala problema kehidupan pemecahannya harus berdasarkan Islam, jika kita kembali kepada masalah kelangkaan pangan yang Malthus kemukakan disebabkan oleh meledaknya populasi penduduk yang tidak diberangi dengan jumlah makanan di dunia, maka kita akan jumpai firman Allah SWT dalam Q.S. I brahim ayat 32-34 dan Q.S. AI-Baqarah ayat 155 sebagaimana telah dijelaskan di atas.

Pada hakikatnya, Allah SWT telah menganugerahkan alam beserta isinya untuk memenuhi kebutuhan manusia. Setiap manusia sudah memiliki bagian atau rizkinya masing-masing sehingga tidak mungkin ada kekurangan dalam hal pangan terkait dengan pertambahan jumlah penduduk yang terjadi. Segala sesuatu yang ada di dunia ini sudah diperhitungkan oleh Allah SWT dan diserahkan kepada manusia sebagai khalifah di bumi ini, maka seyogyanya manusia mampu untuk mengelola dan mengolahnya dengan baik dan benar bukan demi kelangsungan hidup jangka pendek saja melainkan juga jangka panjangnya. Namun, kebodohan, keserakahan dan sikap mubadzir (sia-sia) pada diri manusia itu sendiri yang sering menjadi kendala dalam penyediaan kebutuhan-kebutuhan.

Sikap negatif manusia ini yang menjadi faktor kerusakan, seperti eksploitasi sumber daya alam yang berlebihan sehingga menimbulkan kerusakan-kerusakan lingkungan. Kerusakan yang disebabkan oleh manusia inilah yang diindikasikan menjadi salah satu penyebab terjadinya kelangkaan sumber daya bagi generasi mendatang. Sehingga pada dasarnya kelangkaan pangan di masa mendatang bukan terjadi karena pertumbuhan manusia yang begitu pesat yang tidak diimbangi dengan pertumbuhan sumber daya pangan, akan tetapi hal ini terjadi sebagai akibat dari perbuatan manusia itu sendiri yang tidak benar dalam mengelola dan memanfaatkan sumber daya pangan yang ada.

\section{Implikasi Praktis / Teoritis}

Idealnya teori Malthus mengingatkan kita bahwa pertumbuhan penduduk tetap harus memperhatikan kelestarian lingkungan, artinya harus disesuaikan daya dukung dan daya tampung lingkungan. Hal ini perlu dilakukan karena pembangunan yang dilakukan sekarang ini, jangan sampai merusak ataupun merebut hak-hak generasi masa depan. Pembangunan harus ditujukan untuk mensejahterakan masyarakat sekarang dan generasi masa depan. Teknologi dan 
segala bentuk perkembangannya diharapkan mampu menciptakan kehidupan yang jauh lebih baik di masa sekarang dan juga di masa mendatang.

Keterbasan dan Saran

Penelitian dilakukan dengan metode kualitatif dan menggunakan data primer yang diperoleh dari buku dan sumber-sumber lainnya. Keterbatasan pada penelitian ini adalah minimnya sumber/ referensi yang digunakan oleh peneliti sehingga data yang diperoleh pun kurang lengkap dalam mendukung topik yang diteliti. Sehingga disarankan kepada peneliti selanjutnya untuk lebih memperbanyak referensi penelitian agar mampu mendukung topik yang diteliti dengan lebih baik.

\section{Daftar Pustaka}

Al Arif, N. R. (2017). Pengantar E konomi Syariah Teori dan Praktik. Bandung: CV Pustaka Setia,

An-Nabhani, T. (2011). Peraturan Hidup dalam Islam, Edisi Mu'tamadah, Cet. VII . Jakarta: Hizbut Tahrir Indonesia.

Ash Shadr, M. B. (2008). Buku Induk Ekonomi Islam: Iqtishaduna, Cet. I. Jakarta: Zahra.

Conway, E. (2015). 50 Gagasan Ekonomi yang Perlu Anda Ketahui. Jakarta: Esensi Erlangga Group.

Karim, A. A. (2001). Ekonomi Islam: Suatu Kajian Ekonomi Mikro. Jakarta: Karim Business Konsulting.

Modul Teori Ekonomi Islam (Makro Mikro Islam). Bandung: SCIEmics.

Priyono dan Ismail, Z. (2012). Teori Ekonomi . Surabaya: Dharma IImu.

Quthb, S. (2008). Tafsir Fi Z hilalil Q ur' an (Dibawah N aungan al-Q ur' an), Jilid I. Jakarta: Gema Insani.

Rahmawaty, A. (2011). E konomi M ikro Islam. Kudus: Nora Media Enterprise.

Triono, D. C. (2011). Ekonomi Islam M adzhab H amfara, Jilid I Falsafah Ekonomi Islam, Cet. II. Bantul: Irtikaz.

A prianto, N. E.K. (2016). Kebijakan Distribusi dalam Pembangunan Ekonomi Islam, Jurnal Hukum Islam Vol. 14 No. 2, 73-96. Retrieved From http:/ / media.neliti.com/ media/ publication/ 208922

Novianto, A. (2017). Memperbesar Tentara Cadangan Pekerja: "Bonus Demografi" dan Ekonomi Politik Negara Neoliberal Di Indonesia, Kawistara Vol. 7 No. 2, 187-200. DOI 10.22146/ kawistara.18834

Pieris, K.W.D. (2015). Ketahanan dan Krisis Pangan dalam Perspektif Malthus, Depedensi dan Gender (Women in Development), Jurnal Hubungan Internasional Vol. 8 No.1, 1-13. Retrieved from http:/ / journal.unair.ac.id/ download-fullpapers-jhi6e16f5e39ffull.pdf

Qomar, M. N. (2016). Telaah Kritis Masalah Ekonomi Perspektif Muhammad Baqir Al-Sadr, $\begin{array}{lllllll}\text { Iqtishoduna } & \text { Vol. } & 7 & \text { No.1, } & 1-14 . & \text { Retrieved } & \text { from }\end{array}$ http:/ / ejournal.iaisyarifuddin.ac.id/ index.php/ iqtishoduna/ article/ download/ 80/81/

Subair. (2015). Relevansi Teori Malthus Dalam Diskursus Kependudukan Kontemporer, Dialektika, $\begin{array}{llllll}\text { Vol. } & 9 & \text { No. } & 2, & 96-110 . & \text { Retrieved from }\end{array}$ http:/ / jurnal.iainambon.ac.id/ index.php/ DT/ article/ download/ 224/ 176

Ulum, M. (2017). RO'SUMALIYAH VS SCARCITY: (Paradigma Pelemahan Terhadap Perekonomian Syariah), Jurnal Ummul Qura Vol. 9 No. 1, 69-81. Retrieved from http:/ / ejournal.kopertais4.or.id/ pantura/ index.php/ qura/ article/ download/ 3027/ 2193

Khairiyah, S. (2019). “Cuaca Buruk Picu Kelangkaan Bahan Pangan di Samarinda”, Radio Republik Indonesia, 20 Juni. http:/ / m.rri.co.id/ post/ berita/ mitigasi_bencana/ cuaca_buruk.html (diakses pada 3 Desember 2019)

Maris, S. (2019). Indonesia Terancam Krisis Pangan, Begini Cara Mengatasinya, Liputan6.Com, 17 Mei. A vailable at: https;/ / m.liputan6.com/ news/ read/ 3968578/ (diakses pada 3 Desember 2019)

Putri, V. (2015). Teori Robert Malthus dan Ketahanan Pangan, Kompasiana, 08 Oktober. Available at: https:/ / www.kompasiana.com/ virta_putri/ 56168afbf07e6le8090caeca/ (diakses pada 3 Desember 2019)

Thomas Robert Malthus. Wikipedia Ensiklopedia Berbahasa Indonesia. Available at: https:/ / id.wikipedia.org/ wiki/ Thomas_Malthus (diakses pada 3 Desember 2019)

Setiawan, G.H. (2019). Madzhab Ekonomi Mainstream. Indonesiana. 27 April. Available at: 
SERAMBI, 2(1), 1-14

M una, T.I F \& Q omar, M .N , Scarcity, R obert M althus, Islamic economics...

http:/ / www.indonesiana.id/ read/ 119654

About Authors

Titin Izzatul M una dan M ohammad N urul Q omar adalah mahasiswa dan Dosen di Ekonomi Syariah, Fakultas Ekonomi dan Bisnis Islam, Institut Agama Islam N egeri Kudus 
SERAMBI: Jurnal Ekonomi Manajemen dan Bisnis Islam Published by LPMP Imperium

Accepted author version posted online: 30 April 2020

(c) (i)

(C)2020 The Author(s). This open access article is distributed under a Creative Commons Attribution (CC-BY) 4.0 license 